\title{
Practice and Application of Interactive Teaching in Pesticide Course*
}

\author{
Kailing Peng \\ Key Laboratory of Harmless Pesticide Application \\ Hunan University of Humanities, Science and Technology \\ Loudi, China 417000 \\ Hunan Provincial Collaborative Innovation Center for Field \\ Weeds Control \\ Loudi, China 417000
}

Xiu Liu

Key Laboratory of Harmless Pesticide Application

Hunan University of Humanities, Science and Technology Loudi, China 417000

Hunan Provincial Collaborative Innovation Center for Field Weeds Control

Loudi, China 417000

\section{Yinhua Ma}

Key Laboratory of Harmless Pesticide Application Hunan University of Humanities, Science and Technology Loudi, China 417000

Hunan Provincial Collaborative Innovation Center for Field Weeds Control

Loudi, China 417000

\author{
Chenzhong Jin** \\ Key Laboratory of Harmless Pesticide Application \\ Hunan University of Humanities, Science and Technology \\ Loudi, China 417000 \\ Hunan Provincial Collaborative Innovation Center for Field \\ Weeds Control \\ Loudi, China 417000 \\ **Corresponding Author
}

Yunyun Zhou

Key Laboratory of Harmless Pesticide Application Hunan University of Humanities, Science and Technology Loudi, China 417000

Hunan Provincial Collaborative Innovation Center for Field Weeds Control Loudi, China 417000

\section{Han Xi}

Key Laboratory of Harmless Pesticide Application Hunan University of Humanities, Science and Technology Loudi, China 417000

Hunan Provincial Collaborative Innovation Center for Field Weeds Control Loudi, China 417000

\section{INTRODUCTION}

\begin{abstract}
Pesticide science is a professional, theoretical, practical and technical course related to agriculture. The traditional teaching methods of teacher-centered and classroom teaching cannot meet the demands of professionalism, practicality and technicality in the course. After two years of exploration, the author changed the concepts and methods in the teaching process of this course, adopted interactive teaching, focused on students, mobilized the enthusiasm and participation of students, and strengthened students' thinking ability and practical ability training. Through the reforms, students' ability to find and solve problems was improved, their interest in the course was improved, and their mastery of professional knowledge and application skills were also improved. Besides, excellent teaching effects were achieved.
\end{abstract}

Keywords-pesticide science; course reform; interactive teaching

*Fund Project: Teaching Reform Research Project in Hunan Province (No.: Xiang Jiaotong [2015] No. 291); Teaching Quality Engineering Project in Hunan Province (School-enterprise Cooperation Talent Training Demonstration Base for Agricultural and Biological Sciences, No.: Xiang Jiaotong [2015] No. 274).
In the new situation where people pay more and more attention to environmental safety and living quality, the safety of applying pesticide on food has received more attention. How to use and develop pesticides to prevent and control pests while minimizing harm to the environment has become a hot spot. Therefore, it becomes crucial to cultivate senior applied plant protection technical personnel with innovative thinking and the abilities of finding and solving problems $[1,2]$. Interactive teaching can achieve the training goal. Therefore, it has significantly improved teaching effectiveness by introducing interactive teaching into pesticide teaching, designing many different problem situations, guiding students to read materials before class. Moreover, teachers and students communicating, discussing, solving questions and exploring ways to solve problems in class also enable students to acquire knowledge and skills [3]

\section{THE CHARACTERISTICS OF INTERACTIVE TEACHING}

Interactive teaching has a variety of specific teaching methods, including methods of reading and explaining, 
discussion method, heuristic method, seminar method, method of research project, case and lectures and so on. The interactive teaching requires teachers to have comprehensive, profound, and unique insights. It requires that teachers set attractive situation that is close to the student's life, put forward valuable questions, and are proficient in using modern teaching methods on the basis of understanding the students' original knowledge and abilities. It also asks for students solving problems by searching books, consulting teachers, and discussing with each other.

The interactive teaching mode is a New Normal developed from practice. It aims at providing students with the opportunity to think about and discuss problems, and creating a kind of open scenes and approaches helpful for exploration and discussion during the learning process so that students search, select, and discuss actively centered on a certain topic before processing information, and apply knowledge to solve problems. It helps students to enrich their knowledge, broaden their horizons, and improve their comprehensive abilities, and it also contributes to teachers and students exploring, discovering and studying together, thus improving the relationship between teachers and students as well as promoting teaching and learning [3, 4].

\section{INTERACTIVE TEACHING REFORM PRACTICE OF PESTICIDE COURSE}

\section{A. Natures and Features of Pesticide Courses}

In China, the Pesticide course has a long history and is a compulsory subject for undergraduate colleges specializing in plant protection and agronomy. The course has also been started under the name of "Phytochemistry Protection," and the earliest research on Plant chemical protection teaching was conducted by academician Zhao Shanhuan of South China Agricultural University, and published the first textbook "Phytochemical Protection" in 1980. It has been updated to the fourth edition (edited by Prof. Xu Hanhong), and it can be said that it is the material basis for pesticide teaching. Since the 1980s, Pesticide Teaching and Research Seminar has been held 15 sessions up to now. The seminar has greatly promoted the development of pesticide discipline and trained a large number of professional and technical personnel related to pesticide majors. The course of "Phytochemical Protection" and the course of "Pesticide Science" have been set up in the agricultural specialties, and theoretical and practical teaching courses have been set up. However, the course teaching before was mainly in the form of cramming education, and it was difficult to give full play to students' enthusiasm. Especially for pesticide products, there are various introductions of pesticide products, which make it difficult to remember and apply it in practice. Chinese agricultural colleges also carried out teaching research and reforms on the courses of Pesticide Science and Phytochemical Protection, and strengthened the cultivation of practical and applied abilities [5, 6].

\section{B. Practice and Application of Pesticide Course Teaching Reform}

"Pesticide Science" course is a required course in plant protection specialty, Hunan College of Humanities, Science and Technology, but is set as an optional course in agriculture and horticulture. The teaching contents of the lectures mainly are the basic concepts and principles of pesticides, pesticide agent producing, pesticide resistance and Determination of pesticide biological activity, classification of pesticides, product features, and applied technology, and the professional attributes are strong. At present, the course consists of two parts, theoretical teaching and experimental teaching. The basic theory and experimental operations, and the teaching mode of "cramming education" cannot meet the needs of students' learning. Students have a variety of demands, and most of them are very interested in the contents related to actual production such as identification of insect pests in field, the application technology of pesticides in the field, the identification and treatment of pesticide chemical damage, pesticide resistance, pesticide residue, and pesticide formulation processing. Supposing that based on basic theoretical knowledge, teachers adopt the teaching methods with the theme of integrating into actual production problems through a variety of methods: creating question situations or students raising questions, guiding students to search for information, comprehend texts, discuss interactively, research practice, explore and debate to figure out how to solve problems, students' skills in independent discovery and identification problem, and psychological load capacity for intricate use of pesticides are developed, and they can leave the "crutch" of teachers gradually to "walk" independently, from "learning to do" to "how to do a good learning" and "putting it into practice", and acquire knowledge and skills as well as learn more effectively.

After two years of interactive teaching practice, it was found that most of the students who major in agriculture were interested in the identification, prevention and control of pests and weeds. They were willing to know the research dynamics in the relevant fields to reserve knowledge for working on the prevention and control of pests and weeds after graduation. The previously selected textbook was "Pesticide Science" edited by Prof. Wu Wenjun of the Northwest A\&F University. The textbook focused on the physical and chemical properties and structure of pesticides, while agricultural students emphasized on the application of pesticides. Therefore, they started to use the textbook "Phytochemistry Protection" edited by Prof. Xu Hanhong as a teaching material in 2017, which is consistent with the reexamination recommendatory bibliography of the entrance examination for agriculture postgraduates in plant protection field.

At present, the teaching of the "Pesticide Science" course is based on the requirements of most students and combined with production practices. Besides, it conducts thematic discussions and extracurricular practice such as carrying out field pest and weed recognition, pesticide field application technology, Identification and prevention of pesticide hazard, pesticide leftover detection, and pesticide formulation 
processing, which is an important supplement and improvement to the basic theoretical teaching of the course and enables students to master the systematic theory, practical knowledge, and experience of pesticide science. In addition, two specialized courses "Pesticide Science" and "Weed Science" complement each other. Understanding of "Pesticide Science" especially the chapter of "herbicides" can accelerate the learning of the chapter of "weed controlling techniques" in "Weed Science", and the study of "Weed Science" will also strengthen knowledge of the comprehensive prevention and control of weeds. The course of "Analysis on Pesticide Agent Producing and Residue" has also been created for postgraduate students of agriculture in the field of resources utilization and plant protection. Therefore, the supplement and improvement of the course teaching system of "Pesticide Science" also has an effect on improving the teaching quality and level of graduate students.

\section{CONCLUSION}

More than two years of teaching reform show that it is conducive to cultivating high-level plant protection technology professionals that can not only meet their own development needs, but also serve social and industrial needs by carrying out selective class topic interactive discussion, interchanging theory teaching with hands-on practice, and constructing the practical training module with theory and practical teaching as the main body and production practice as the carrier according to students' interests and hobbies, while teaching basic theoretical knowledge of "Pesticide Science" in class. It can fully arouse students ' study enthusiasm, and stimulate their desires for knowledge and innovation.
马德英, 羞松, 张新. 新形势下植物化学保护课程的教学改革与探 索[J]. 科教导刊(上旬刊), 2013, 12: 176-177.

\section{REFERENCES}

[1] Song Baoan, Zhao Degang, Yang Song, Jin Linhong, Xue Wei, Ouyang Guiping, Xie Chengwei, Yu Jianping, Hu Deyu. Construction and Practice of Pesticide Innovative Talents Training System [J]. Journal of Guizhou University (Natural Science Edit), 2014, 01:130136. 宋宝安, 赵德刚, 杨松, 金林红, 薛伟, 欧阳贵平, 谢承卫, 郁建 平, 胡德禹. 农药学创新型人才培养体系的构建与实践 [J]. 贵州大 学学报(自然科学版), 2014, 01:130-136.

[2] Wang Yi, Wu Xiangwei, Gao Qian, Cao Haiqun, Hua Rimao. Reform and exploration of pesticide curriculum in Higher Agricultural and Forestry universities [J]. Guangzhou Chemical Industry, 2017, 45(07): 143-144. 王毅, 吴祥为, 高倩, 操海群, 花日茂. 高等农林院校 农药学课程改革与探索[J]. 广州化工, 2017,45 (07):143-144.

[3] Du Yanying, Chen Yun. Exploration and Practice of Interactive Teaching Method in University Classroom Teaching [J]. Education Forum, 2018, 04: 171-172. 杜艳迎, 陈云. 互动式教学方法在大学 课堂教学中的探索和实践 [J]. 教育教学论坛,2018,04: 171-172.

[4] Zeng Xinnian, Xu Hanhong, Hu Meiying. Discussion on Pesticide Teaching Practice and Reform[J]. Higher Agricultural Education, 2003, 01: 73-74. 曾金金年, 徐汉虹, 胡美英. 农药学教学实践与改革 的探讨 [J]. 高等农业教育, 2003, 01: 73-74.

[5] Qian Kun, He Lin, Deng Xinping, Ma Guanhua, Li Fulin, Yang Qian. A Brief Discussion on Education Reform and Problems in Pesticide Teaching[J]. China Plant Protection, 2012, 12:59-60. 钱坤, 何林, 邓 新平, 马冠华, 李福林. 杨倩. 农药学教学中存在的问题及教改思路 浅谈[J]. 中国植保导刊, 2012, 12:59-60.

[6] Ma Deying, Qiang Song, Zhang Xin. Teaching Reform and Exploration of Plant Chemical Protection Course under the New Situation [J]. The Guide of Science \& Education, 2013, 12: 176-177. 